\title{
Exploring the Effects of Occupational Psychological Disorders on Construction Employees and the Construction Industry
}

\author{
Genevieve Ataa Fordjour ${ }^{*}{ }^{\circledR}$, Albert P. C. Chan 1 , Peter Amoah ${ }^{2}$, Audrey Amponsah Fordjour ${ }^{3}$ \\ ${ }^{1}$ Department of Building and Real Estate, The Hong Kong Polytechnic University, Hong Kong, China \\ ${ }^{2}$ Department of Building Technology, Kwame Nkrumah University of Science and Technology, Kumasi, Ghana \\ ${ }^{3}$ Department/School of Social Work, University of Northern British Columbia, Prince George, Canada \\ Email: ^genevievefordjour@gmail.com, albert.chan@polyu.edu.hk, peteramoah@knust.edu.gh, \\ audrey.fordjour@alumni.unbc.ca
}

How to cite this paper: Fordjour, G.A., Chan, A.P.C., Amoah, P. and Fordjour, A.A. (2020) Exploring the Effects of Occupational Psychological Disorders on Construction Employees and the Construction Industry. Occupational Diseases and Environmental Medicine, 8, 1-25.

https://doi.org/10.4236/odem.2020.81001

Received: December 13, 2019

Accepted: January 6, 2020

Published: January 9, 2020

Copyright (๑) 2020 by author(s) and Scientific Research Publishing Inc. This work is licensed under the Creative Commons Attribution International License (CC BY 4.0).

http://creativecommons.org/licenses/by/4.0/

\begin{abstract}
Construction employees could experience occupational psychological disorders, such as workaholism and burnout due to their work, personality characteristics or lifestyle. This study sought to explore the effects of psychological disorders on construction employees and the construction industry. To achieve this aim, both the methods of focus group discussions and survey questionnaire were employed. The focus group discussions revealed 17 potential effects and 12 potential effects of psychological disorders on the construction employees and the construction industry respectively. A quantitative study was then employed to determine the key effects and to test the reliability of the findings from the focus group study. The results revealed that the highly perceived effects of psychological disorders on construction employees were accident-prone, chronic pain, insomnia or sleep disturbances, as these had the highest mean scores. The key effects also identified as perceived effects of construction employees' psychological health conditions on the construction industry were: absenteeism/sick leave, errors in work, job dissatisfaction and increased medical costs. Exploratory factor analysis was employed, and the 17 effects on construction employees were categorized under behavioural effects and physiological effects. The 12 effects on the construction industry were also categorized under direct costs and indirect costs. The results from this study confirm the need for strategic interventions to mitigate the effects of occupational psychological disorders on construction employees and the construction industry of Ghana and to some extent globally. The exploratory nature of the study using preliminary findings from focus group discussions contributes to the literature on occupational health psychology.
\end{abstract}




\section{Keywords}

Occupational Psychology, Psychological Effects, Psychological Disorders, Construction Industry, Construction Employees

\section{Introduction}

Construction employees specifically construction project team members and trade workers are the most significant project resources as they have a direct impact on a construction project's outcome in terms of time, quality and cost (Çelik and Oral, 2019; Leung, et al., 2016; Boschman, et al., 2013) [1] [2] [3]. Given that the nature of the construction work is complicated, crisis-ridden, dynamic and involves high speed, construction employees could be vulnerable to the experience of occupational psychological disorders with effects on themselves and the construction industry (Sommovigo, et al., 2019; Bowen, et al., 2014a; Leung and Chan, 2012) [4] [5] [6]. Occupational psychological disorders such as workaholism, burnout, depression, and anxiety are conditions which are characterized by negative emotions, altered thoughts and behaviours with associated distress and impaired functioning of one's abilities (WHO, 2005) [7]. Symptoms of occupational psychological disorders such as sleep problems, fatigue, worry, and irritability are common among the working group, and these conditions could have a significant impact on employees' quality of life and ability to function adequately in their respective fields (Hassard and Cox, 2016; Wang, et al., 2017) [8] [9].

The disparity between what is expected and demanded from the employees and their ability to handle the circumstances often leads to the experience of occupational psychological disorders (Lazarus and Folkman, 1984; O’Donoghue, et al., 2016) [10] [11]. Construction work-related factors such as tight time schedules, poor working conditions, complex methods, and complicated working relations also expose construction employees to the risks of occupational psychological disorders (Sommovigo, et al., 2019; Boschman, et al., 2013; Chan, et al., 2016) [3] [4] [12]. The risk factors that could lead to occupational psychological disorders in the construction workplace have been categorised under organisational, task, physical and personal factors (Leung, et al., 2012) [13]. Previous studies have revealed that psychological disorders such as stress have significant effects on individuals and the construction organisation (Bowen, et al., 2014b, Boschman, et al., 2013; Yang, et al., 2017) [3] [14] [15]. These effects include reduced productivity, high absenteeism, increased health problems and high compensation costs (Leung, et al., 2017; Finney, et al., 2013) [16] [17]. Most of the previous studies investigate mainly the effects of a single form of psychological disorder specifically stress effect on individuals and the construction organisation (Chan, et al., 2016; Bowen, et al., 2014a; Leung, et al., 2017) [5] [12] [16]. This study sought to explore the effects of the broader taxonomies of psycholog- 
ical disorders such as workaholism and burnout on construction employees and the construction industry, based on the research participants' personal experiences, opinions and or perceptions.

\section{Background of study}

Occupational psychological disorders could affect the physical and emotional health of a person (Mehta and Chaudhary, 2005; Wang, et al., 2017) [9] [18]. The effects of psychological disorders on a person's physical health could be identified from various indicators such as headaches, loss of sleep and gastrointestinal disorders (Ganster and Rosen, 2013; Enshassi, et al., 2016) [19] [20]. The effects on emotional health can also be manifested in various forms such as frustration, anxiety and quick temperament (Baba, et al., 2009) [21]. The Chartered Institute of Building (CIOB) revealed that about $70 \%$ of employees in the construction industry suffer from psychological disorders such as stress, depression, and anxiety (CIOB, 2006) [22].

Psychological ill-being of employees could have several implications on interpersonal relationship, task and project performance of the construction industry (Chan, et al., 2012) [23]. A study by the Health and Safety Executive (2007) [24] revealed that about 10.5 million workdays are lost yearly to work-related psychological health conditions and physical illness. The effects of construction workers' psychological ill-being also include ineffectiveness, poor communication, low morale, low productivity, absenteeism, high job turnover, poor work relations, poor organisational climate, and accidents in the workplace (Fordjour and Chan, 2019; Leung and Chan, 2012; Chan, et al., 2012) [6] [23] [25].

The occupational psychological conditions of employees have been grouped under broad taxonomies namely: burnout and workaholism (Russell, 2003; O'Donoghue, et al., 2016) [11] [26]. Previous studies revealed that occupational psychological disorders of burnout and workaholism are not harmful, but high levels of these conditions could have detrimental effects on the behavioural and organisational outcomes of the construction industry (Leung, et al., 2016; Boschman, et al., 2013) [2] [3]. Some researchers have also argued about the positive effects of some level of psychological health conditions on employees' productivity and performance (Russell, 2003; Kahya, 2007; Gruman and Saks, 2011) [26] [27] [28].

Russell (2003) [26] designed a theoretical model of positive and negative effects of occupational psychological conditions known as the core affect circumplex. The core effect describes a person's neurophysiological state and underlies good or bad feelings. The circumplex of core affects developed by Russell (2003) [26], comprised of four axes of emotions, which ranges from pleasant to unpleasant emotions and high work activation to low work activation. This was done to indicate the intensity of psychological health conditions and the work activation levels of employees having these psychological conditions (O’Donoghue, et al., 2016) [11]. Psychology health conditions have also been categorised into five subgroups depending on the severity such as normal, mild, 
moderate, severe and extreme levels (Millward, 2006; Offei and Quansah, 2009) [29] [30].

It is essential to assess the perceived effects of occupational psychological disorders on construction employees and the construction company (Loosemore, 2009) [31]. This will enable appropriate measures to be taken to eliminate those factors that lead to the adverse consequences of psychological conditions and promote the factors that lead to positive effects.

\subsection{Effects of Burnout as an Occupational Psychological Disorder}

Burnout is a critical issue in the occupational psychological literature and has been found to correlate with many important organisational constructs such as turnover intentions, job satisfaction and organisational commitment (Alarcon, 2011) [32]. Burnout can be described as a prolonged reaction or response to chronical emotions, interpersonal and work stressors, as well as exhaustion of physical, emotional strength or motivation usually because of prolonged stress or frustration (Maslach, et al., 2001) [33]. Burnout as a syndrome of occupational psychological health condition emerges when workers are exposed to working conditions and environments that are stressful (Enshassi, et al., 2016) [20]. Low work resources and high demands of work are some of the possible causes that lead to employees experiencing the psychological health condition of burnout (Demerouti, et al., 2001) [34]. In addition, Colman (2003) [35] also stated that burnout is an acute stress reaction that is characterised by exhaustion resulting from overworking.

The effects of burnout on individuals have been classified to include the dimensions of inefficacy, cynicism, and exhaustion, which could lead to lack of interest in the work context (Maslach, et al., 2001) [33]. The effects of burnout could also be manifested in the form of anxiety, fatigue, insomnia, depression, and impairment in work performance (Colman, 2003) [35]. Workers experiencing burnout can also be associated with work displeasure and low levels of work activation or motivation (O'Donoghue, et al., 2016; Fordjour and Chan, 2019) [11] [25]. Emotional exhaustion which is a characteristic of burnout is a psychological state with the victims lacking motivation or energy to work (Demerouti, et al., 2010) [36]. Also, Maslach et al., (2001) [33] stated that emotional exhaustion is the central element in the effect of burnout. Anxiety and sleep disorders have also been found to be linked with construction workers experiencing burnout, and these could indirectly affect the overall success of the construction project (Leung, et al., 2012) [13].

\subsection{Effects of Workaholism as an Occupational Psychological Disorder}

Workaholism can be defined as the uncontrollable need or compulsion to work hard incessantly (Oates, 1971) [37]. Workaholism is also described by Oates (1971) [37], as the strong and irresistible inner drive in a person, forcing him or 
her to work hard excessively. Van Beek, et al. (2012) [38] identified two forms of motivation which result in workaholism namely: introjected regulation and identified regulation. Introjected regulation is described as the extrinsic controlled element of motivation in people to work hard to receive praises, award or to avoid criticisms. Identified regulation is also the extrinsic autonomous element of motivation in a person to act because he or she has accepted and identifies with the reasons associated with working hard (Van Beek, et al., 2012) [38].

Workaholism has been conceptualized by Spence and Robbins (1992) [39], with the workaholic triad including the dimensions of job involvement, work drive, and reduced working enjoyment. Workaholism, therefore, has cognitive and behavioural components (McMillan, et al., 2003) [40]. The cognitive component is present when a person thinks persistently about his or her work and work hard compulsively. The behavioural component, on the other hand, is manifested where a person has a strong inner drive to work hard (McMillan, et al., 2003) [40]. These are likely to have negative consequences on the health of the individual construction worker. A study by Schaufeli, et al. (2008) [41] also revealed that employees who are workaholics are agitated, tensed and they work compulsively to meet standards set internally by themselves, or externally by their work superiors. Workaholics have high tendency to work hard excessively, but they tend to be obsessed with their work (O'Donoghue, et al., 2016) [11]. Though employees experiencing workaholism have high levels of activation or energy towards their work, they experience displeasure (Russell, 2003) [26]. Workaholism could also cause impairment of a person's well-being, with symptoms such as fatigue, chronic tension and sleep disorders (Pennonen, 2011) [42]. This makes workaholism a negative state of the occupational psychological condition of employees, with possible adverse effects on the construction industry such as increased rate of accidents and injuries at the construction workplace (Bowen, et al., 2014; Leung, et al., 2017) [5] [16].

The negative state of occupational psychological conditions such as burnout and workaholism are not diseases, but if they become intense and goes on for some time without proper management, they can lead to a mental and physical ill-health of the employees (Demerouti, et al., 2010; Yang, et al., 2017) [15] [36]. Construction employees experiencing occupational psychological conditions of workaholism and burnout could be associated with anxiety and sleep disorders; and these could, directly and indirectly, affect the overall success of the construction project (Wang, et al., 2017; Leung, et al., 2012; Chan, et al., 2016) [9] [12] [13].

\section{Research Methodology}

This study adopted methods of both qualitative and quantitative research to explore the perceptions of construction employees on the effects of occupational disorders on themselves and the construction industry. The study was conducted in Ghana, with a total of 390 construction employees purposively sampled from 
the construction industry in Ghana as the research participants for both the qualitative and quantitative study. Firstly, the methods of the focus group study under the qualitative research approach were employed with 90 research participants, which was then followed by the quantitative survey questionnaire with 300 respondents. The preliminary data collected using focus group discussion was intended to reveal findings which were unique and have not yet been revealed in previous studies. A detailed description of the focus group process have been provided in the next section and the results obtained from the focus group discussions have also been presented under Table 2 and Table 3. This focus group method also seeks to penetrate the thoughts and emotions of individuals in a personalised way than the quantitative method (Ashleigh and Mansi, 2012) [43]. The findings from the qualitative study were then used to develop the questionnaire for the questionnaire survey.

The purposive sampling was employed for the selection of the research participants for both the focus group study and questionnaire survey. The research participants were selected on the basis that 1) they belong to either a construction professionals' group or a construction trade workers' group and 2) they work in a Ghanaian construction company. The construction professionals comprised of quantity surveyors, engineers, contractors, architects, construction managers, project managers and supervisors. The construction trade working group included: masons, carpenters, steel benders, plumbers, and others.

\subsection{Ethical Considerations}

Research ethics considered in this study included allowing respondents to voluntarily participate in the study based on their free will, without any form of coercion. Participants also filled informed consent to be used for the study. Permission was also sought from the research participants for instance, to audio record them during the focus group discussion. The moderator also assured prospective respondents that the results from the study would not put any respondents at any risks of criminal or civil liability, nor affect the respondents' reputation employability or financial standing. The personal information of the research participants were, therefore, treated with confidentiality.

\subsection{The Focus Group Study Method}

The focus group method is an exploratory research technique for collecting data from interactive and dynamic group discussions (Cooper and Schindler, 2006) [44]. The focus group study was introduced in 1956 by a sociologist called Merton in 1956 (Leung and Chan, 2012) [6]. The method of focus group discussion is one of the qualitative research methods, that are widely used for research studies as they produce more detailed and richer context information (Ashleigh and Mansi, 2012) [43]. The focus group method was used to gather respondents within the same construction organisation together in an informal group setting to discuss the subject matter. 
A total of sixteen (16) focus group discussions were held in Ghana from the period of May 2018 to July 2018, with a total of 90 research participants. The discussions were held separately for the construction professionals or project team members and the construction trade workers purposively selected from twelve (12) construction firms in Ghana. The construction trade workers group consisted of employees such as carpenters, masons, welders, steel benders, painters, and electricians. The construction professionals group also consisted of architects, contractors, engineers, and quantity surveyors. The background information of the research participants for the focus group study has been shown in Table 1.

Table 1. Background information of the Research Participants.

\begin{tabular}{|c|c|c|c|}
\hline \multirow{2}{*}{ Information } & \multirow{2}{*}{ Categories } & \multicolumn{2}{|c|}{$\begin{array}{c}\text { Percentage distribution of } 90 \text { research participants } \\
\text { (45 Participants each) }\end{array}$} \\
\hline & & $\begin{array}{c}\text { Construction } \\
\text { Professionals group }\end{array}$ & $\begin{array}{l}\text { Construction Trade } \\
\text { workers group }\end{array}$ \\
\hline \multirow[t]{4}{*}{ Age } & $25-35$ & $27 \%$ & $20 \%$ \\
\hline & $36-45$ & $40 \%$ & $40 \%$ \\
\hline & $46-55$ & $20 \%$ & $29 \%$ \\
\hline & $>55$ & $13 \%$ & $11 \%$ \\
\hline Years of & Less than 1 year & $16 \%$ & $4 \%$ \\
\hline working & $1-5 \mathrm{yrs}$ & $16 \%$ & $24 \%$ \\
\hline \multirow[t]{2}{*}{ experience } & $6-10 \mathrm{yrs}$ & $28 \%$ & $60 \%$ \\
\hline & Above 10yrs & $40 \%$ & $12 \%$ \\
\hline Level of & $\begin{array}{l}\text { Ghana Certificate } \\
\text { Exams "A" level }\end{array}$ & $13 \%$ & $4 \%$ \\
\hline \multirow[t]{5}{*}{ Education } & $\begin{array}{l}\text { Ghana Certificate } \\
\text { Exams "O" level }\end{array}$ & $7 \%$ & $2 \%$ \\
\hline & $\begin{array}{l}\text { Junior High } \\
\text { School level }\end{array}$ & $2 \%$ & $38 \%$ \\
\hline & $\begin{array}{l}\text { Secondary } \\
\text { School level }\end{array}$ & $7 \%$ & $9 \%$ \\
\hline & $\begin{array}{l}\text { Technical or } \\
\text { Vocational level }\end{array}$ & $42 \%$ & $40 \%$ \\
\hline & $\begin{array}{l}\text { Graduate-level } \\
\text { or Above }\end{array}$ & $29 \%$ & $7 \%$ \\
\hline \multirow[t]{2}{*}{ Marital Status } & Married & $80 \%$ & $71 \%$ \\
\hline & Single & $20 \%$ & $29 \%$ \\
\hline \multirow[t]{2}{*}{ Gender } & Male & $76 \%$ & $91 \%$ \\
\hline & Female & $24 \%$ & $9 \%$ \\
\hline
\end{tabular}


The construction professionals formed 9 focus groups and the construction trade workers formed 7 focus groups. Each focus group which lasted for a maximum of 1 hour comprised of a minimum of five (5) and a maximum of seven (7) participants and was led by a moderator. It has been suggested that a focus group should be comprised of five (5) to ten (10) participants, to allow for a balance between the breadth and depth of the data collection (Krueger and Casey, 2000) [45]. The focus group number of sixteen (16) and the sample size of ninety (90) participants could be relatively low. It should be noted however that, large focus group numbers and sample size are uncommon for a focus group study in areas like occupational psychology, which involves people feelings and emotions (Millward, 2006) [29].

\subsubsection{Design of Questions for Focus Group Study}

Open-ended questions were suitable for the exploratory nature of focus group methods. These types of questions stimulate discussions on the research topic (Krueger and Casey, 2000) [45]. The research questions for the focus group discussions were: 1) What do you perceive based on your personal experiences or opinions are the effects of psychological disorders such as workaholism and burnout on construction employees? and 2) What are the perceived based on your personal experiences or opinions are the effects of construction employees' psychological health conditions on the construction industry?

\subsubsection{Data Collection Procedure for Focus Group Study}

Each focus group discussion began with the moderator describing the aim of the research study to the participants. The participants were then encouraged to share their personal experiences, opinions or perceptions on the subject for discussion. Ground rules for the focus group were set, with emphasis on the confidentiality of all information provided by participants during the focus group discussion. The research questions were provided to the participants in both English and the local dialect of "twi". The participants were asked to express themselves in both the English and local dialect, whichever was preferable to them. Possible answers from secondary sources of data were provided to the participants by the moderator for illustration purposes. This also gave further clarifications to the research questions. Individual worksheets were also distributed to each participant to express their own views onto the paper. This initial exercise was intended to allow each participant equal voice in the focus group study. This further enhanced the anonymity and confidentiality of personalised information. The papers submitted with their individual responses were then placed on the ground for further discussion.

Audiotaping and note-taking were used to collect data from the responses during the focus group discussion. To confirm the results from the focus group discussion, the summary of the responses with items identified were read out by the moderator to the research participants. The duration of each sixteen (16) focus group discussion was one (1) hour. The responses from the 16 focus groups were put together for the further research study. 


\subsubsection{Results of the Focus Group Study}

The data collected from all 16 focus group discussions held were gathered and summarized using content analysis. The participants revealed seventeen (17) items as perceived effects of psychological disorders on construction employees. The study also identified twelve (12) items as perceived effects of construction employees' psychological health conditions on the construction industry. The results from the focus group study with some excerpts from the discussions are presented herein in Table 2 and Table 3.

Table 2. Summary of responses on the perceived effects of psychological disorders on construction employees.

\begin{tabular}{|c|c|c|}
\hline Code & Theme identified & Excerpts from focus group discussion \\
\hline E1 & Chronic pain & I get chronic pain all over my body after working so hard for long hours at the construction workplace. \\
\hline E2 & $\begin{array}{l}\text { Coronary } \\
\text { heart disease }\end{array}$ & $\begin{array}{l}\text { I know of a construction worker who suffered from coronary heart disease and was hospitalized for long } \\
\text { periods due to excessive work demands. }\end{array}$ \\
\hline E3 & $\begin{array}{l}\text { Lose valuable things } \\
\text { like job, relationships } \\
\text { and status }\end{array}$ & $\begin{array}{l}\text { The demanding nature of my work has placed me at the point that I have lost valuable things like extra jobs, } \\
\text { relationships and some social status. }\end{array}$ \\
\hline E4 & $\begin{array}{l}\text { Loss memory/ } \\
\text { forgetfulness }\end{array}$ & Anytime I overwork myself I experience loss of memory or forgetfulness. \\
\hline E5 & Accident-prone & $\begin{array}{l}\text { I get injured a lot during work because when my attention is fully on the demanding task, I tend to ignore } \\
\text { safety rules and become prone to } \\
\text { accident. }\end{array}$ \\
\hline E6 & High blood pressure & $\begin{array}{l}\text { There was a time I was threatened to work excessively hard and the } \\
\text { impulse or fear resulted in me having high blood pressure. }\end{array}$ \\
\hline E7 & $\begin{array}{l}\text { Insomnia or sleep } \\
\text { disturbances }\end{array}$ & $\begin{array}{l}\text { The project I am working on has delayed, so workers are supposed to work for long hours throughout the } \\
\text { night with little time for sleeping, this has given me insomnia, as my regular sleep pattern has been disturbed. }\end{array}$ \\
\hline E8 & Stroke or Cancer & $\begin{array}{l}\text { Some construction employees have suffered stroke or cancer due to the poor working conditions with no time } \\
\text { for regular exercise and other } \\
\text { unhealthy habits. }\end{array}$ \\
\hline E9 & Headache & When I work continuously for long hours I get a headache. \\
\hline E10 & $\begin{array}{l}\text { Musculoskeletal } \\
\text { injuries }\end{array}$ & Musculoskeletal injuries are very common with construction employees due to the nature of our work. \\
\hline E11 & Family problems & $\begin{array}{l}\text { I am having family problems because of my work, as my wife complains } \\
\text { I do not have time for the family since I have become so engaged at work lately. }\end{array}$ \\
\hline E12 & Sexual dysfunction & $\begin{array}{l}\text { When there is a heavy workload at the construction site, I become anxious and worry about my work, this } \\
\text { makes me sexually dysfunctional at times. }\end{array}$ \\
\hline E13 & Diabetes mellitus & $\begin{array}{l}\text { I have been diagnosed with diabetes mellitus, which I believe resulted from the poor working conditions that } \\
\text { made me adopt certain lifestyle affecting my health. }\end{array}$ \\
\hline E14 & Feeling faint or dizzy & Working under stressful working conditions makes me feel like fainting or becomes dizzy. \\
\hline E15 & $\begin{array}{l}\text { Loss of motivation, } \\
\text { energy or interest }\end{array}$ & $\begin{array}{l}\text { After putting all my energy into work with the expectation of getting some recognition from the superiors, I } \\
\text { did not get any such as I expected, from that time I have lost my motivation, energy and interest in working } \\
\text { hard for the company. }\end{array}$ \\
\hline E16 & Tightness in the chest & Anytime I am overwhelmed with work I feel some tightness in the chest. \\
\hline E17 & Dietary extremes & $\begin{array}{l}\text { When there is work pressure on me, I tend to eat very little as compared to my usual days when I eat a lot, } \\
\text { thus, moving from one dietary extreme to another. }\end{array}$ \\
\hline
\end{tabular}


Table 3. Summary of responses on the perceived effects of occupational psychological disorders on the construction industry.

\begin{tabular}{|c|c|c|}
\hline Code & Theme identified & Excerpts from focus group discussion \\
\hline F1 & Poor work performance & $\begin{array}{l}\text { Psychological ill-being leads to poor work performance as workers are not in their full capacity to work } \\
\text { well. }\end{array}$ \\
\hline $\mathrm{F} 2$ & Low motivation & $\begin{array}{l}\text { Most of my colleague workers have low motivation to work extra hard these days, because of depression } \\
\text { which results from the unfair rewards given to workers as compared to the efforts we put into the job. }\end{array}$ \\
\hline F3 & Low productivity & The productivity of construction employees becomes low when they have a poor health condition. \\
\hline F4 & High turnover & $\begin{array}{l}\text { When construction employees are not feeling well, they leave the construction industry and high turnover } \\
\text { could affect the company. }\end{array}$ \\
\hline F5 & Low morale & When I reach a certain limit, I have low morale to continue working. \\
\hline F6 & Job dissatisfaction & Job dissatisfaction is a consequence of too much pressure at the workplace. \\
\hline F7 & Absenteeism/ Sick leave & $\begin{array}{l}\text { Construction employees who are having some health problems usually absent themselves from work or take } \\
\text { long sick leave. }\end{array}$ \\
\hline F8 & $\begin{array}{l}\text { Breakdown in commu- } \\
\text { nication }\end{array}$ & $\begin{array}{l}\text { Construction employees do not relate well with each other when there is a lot of tension at the construction } \\
\text { workplace and this leads to a breakdown in communication. }\end{array}$ \\
\hline F9 & Work stoppage & The construction work can be stopped if more employees are not having good health to work. \\
\hline F10 & Violence at work & $\begin{array}{l}\text { Violence at work usually occurs when some construction employees are experiencing psychological health } \\
\text { conditions such as stress, tension or frustration. }\end{array}$ \\
\hline F11 & Medical costs & $\begin{array}{l}\text { Medical costs for the construction industry increase when construction employees are hospitalized because } \\
\text { of their work. }\end{array}$ \\
\hline F12 & Errors in work & $\begin{array}{l}\text { When construction employees are over-exhausted, there can be errors in their decisions, leading to so many } \\
\text { mistakes at work. }\end{array}$ \\
\hline
\end{tabular}

\subsection{The Survey Questionnaire Method}

A scientific research approach requires a systematic and relevant data collection, observation of people objectively and validation of adopted techniques (Ashleigh and Mansi, 2012) [43]. This research sought to determine the highly perceived effects revealed from the focus group study. To achieve this aim of the study, a target of 300 questionnaires were purposively distributed to 150 construction professionals and 150 construction trade workers in Ghana. The target population for the study was 32 construction firms who were registered with the $\mathrm{Ku}$ masi and Accra Metropolitan Assembly. The background information of the respondents for the study has been shown in Table 4 for the construction professionals' group and Table 5 for the construction trade workers group.

\subsubsection{Questionnaire Design}

The closed-ended types of questions used to design the questionnaire focused on the subject matter and aimed to cover the objectives of the research. The respondents were requested to indicate their perceptions on the level of likelihood of effects of psychological disorders presented in the questionnaire, using a 5-point Likert scale with the following qualifications: "Most likely" rated as 5 points, "Likely" rated as 4 points, "Neutral" rated as 3 points, "Unlikely" rated as 2 points, and "Most unlikely" rated as 1 point (Fordjour, et al., 2019) [46]. 


\subsubsection{The Hypotheses for the Study}

The study sought to determine whether there is some relation between variables and to establish whether the test hypothesis should be rejected or not.

For this study the null hypotheses tested were:

1) There is no statistically significant variable measured as effects of occupational psychological disorders.

2) There is no significant difference statistically between the mean scores obtained from construction professionals "a" and construction trade workers "b" for all variables measured.

Table 4. Background information of the Construction professionals' group participants.

\begin{tabular}{|c|c|c|}
\hline \multirow{2}{*}{ Information } & \multirow{2}{*}{ Categories } & \multirow{2}{*}{$\begin{array}{c}\text { Percentage distribution } \\
\text { (150 Participants) }\end{array}$} \\
\hline & & \\
\hline \multirow[t]{4}{*}{ Age } & $25-35$ & $27 \%$ \\
\hline & $36-45$ & $40 \%$ \\
\hline & $46-55$ & $20 \%$ \\
\hline & $>55$ & $13 \%$ \\
\hline \multirow[t]{7}{*}{ Work Trade } & Architect & $16 \%$ \\
\hline & Contractor & $16 \%$ \\
\hline & Engineer & $29 \%$ \\
\hline & Quantity Surveyor & $18 \%$ \\
\hline & Supervisor & $12 \%$ \\
\hline & Construction Manager & $7 \%$ \\
\hline & Project Manager & $2 \%$ \\
\hline \multirow[t]{4}{*}{ Years of working experience } & Less than 1 year & $7 \%$ \\
\hline & $1-5 \mathrm{yrs}$ & $42 \%$ \\
\hline & $6-10$ yrs & $31 \%$ \\
\hline & Above 10 yrs & $20 \%$ \\
\hline \multirow[t]{6}{*}{ Level of Education } & GCE “A” level & $2 \%$ \\
\hline & GCE “O” level & $0 \%$ \\
\hline & Junior High School level & $2 \%$ \\
\hline & Secondary School level & $4 \%$ \\
\hline & Technical or Vocational level & $40 \%$ \\
\hline & Tertiary level or Above & $51 \%$ \\
\hline \multirow[t]{2}{*}{ Marital Status } & Married & $80 \%$ \\
\hline & Single & $20 \%$ \\
\hline \multirow[t]{2}{*}{ Gender } & Male & $87 \%$ \\
\hline & Female & $13 \%$ \\
\hline
\end{tabular}


Table 5. Background information on the Construction trade workers group participants.

\begin{tabular}{|c|c|c|}
\hline \multirow{2}{*}{ Information } & \multirow{2}{*}{ Categories } & \multirow{2}{*}{$\begin{array}{c}\text { Percentage distribution } \\
\text { (150 Participants) }\end{array}$} \\
\hline & & \\
\hline \multirow[t]{4}{*}{ Age } & $25-35$ & $20 \%$ \\
\hline & $36-45$ & $40 \%$ \\
\hline & $46-55$ & $29 \%$ \\
\hline & $>55$ & $11 \%$ \\
\hline \multirow[t]{10}{*}{ Work Trade } & Carpenter & $27 \%$ \\
\hline & Concreter & $31 \%$ \\
\hline & Plumber & $11 \%$ \\
\hline & Welder & $2 \%$ \\
\hline & Steel bender & $9 \%$ \\
\hline & Plasterer & $7 \%$ \\
\hline & Painter & $4 \%$ \\
\hline & Electrician & $5 \%$ \\
\hline & Plant and Equipment Operator & $2 \%$ \\
\hline & Plant and Equipment Mechanic & $2 \%$ \\
\hline \multirow[t]{4}{*}{ Years of working experience } & Less than 1 year & $4 \%$ \\
\hline & $1-5 \mathrm{yrs}$ & $24 \%$ \\
\hline & $6-10 \mathrm{yrs}$ & $60 \%$ \\
\hline & Above 10 yrs & $12 \%$ \\
\hline \multirow[t]{6}{*}{ Level of Education } & GCE “A” level & $4 \%$ \\
\hline & GCE “O” level & $2 \%$ \\
\hline & Junior High School Level & $38 \%$ \\
\hline & Secondary School level & $9 \%$ \\
\hline & Technical or Vocational level & $40 \%$ \\
\hline & Tertiary level or Above & $7 \%$ \\
\hline \multirow[t]{2}{*}{ Marital Status } & Married & $71 \%$ \\
\hline & Single & $29 \%$ \\
\hline \multirow[t]{2}{*}{ Gender } & Male & $96 \%$ \\
\hline & Female & $4 \%$ \\
\hline
\end{tabular}

The alternative hypotheses to be considered after the null hypothesis has failed are as follows:

1) There are statistically significant items measured as effects of occupational psychological disorders.

2) There is a significant difference statistically between the mean values obtained from the construction professionals' group "a" and construction trade 
workers' group "b".

The test statistics value was 0.05 . If the p-value is less than or equal to 0.05 , this means the difference in the mean values is statistically significant, and hence the null hypothesis will be rejected, and the alternative hypothesis considered. If the $\mathrm{p}$-value is however greater than 0.05 , the null hypothesis will not be rejected (Fordjour, et al., 2019) [47].

\subsubsection{Data Analysis}

The data obtained from the questionnaire were organized and subjected to analysis using the Statistical Package for Social Scientists, version 19. Descriptive statistical forms such as mean and standard deviation were used to depict the frequency distribution of the results collated. Inferential statistics such as one sample T-test was employed to measure the significance level of the test variables as effects of occupational psychological disorders perceived by all the respondents, obtained by comparing the means of the true mean/ variable mean and the midpoint of the test variable, which is 3.

Exploratory factor analysis was employed to group the variables into constructs with similar phenomena (Enshassi, et al., 2016) [20]. To establish whether the data obtained were suitable for factor analysis, the Kaiser-Meyer-Olkin (KMO) measure of sampling was employed. The measure for multivariate normality of the variables was determined by Bartlett's test of sphericity. Varimax rotation method and principal component analysis method were employed for the extraction analysis. The number of constructs extracted was based on Eigenvalues greater than 1 and factor loadings of the variables were greater than 0.50 . The internal consistency and reliability of the variables grouped under a construct were determined by Cronbach's Alpha.

The data was assessed to be normally distributed by Blom's fractional rank estimation method (Lo, 2018) [48]. Independent two-sample T-test was employed to assess whether the mean scores obtained from the construction professionals' group statistically differed from the mean values obtained from the construction trade workers group. Levene's Test for equality of variances was employed under the analysis of independent two-sample T-test.

Relative importance index (RII) was used to calculate the ranks of the perceived effects as determined by the research participants.

The RII formula used is as follows:

$$
\mathrm{RII}=\frac{\Sigma W}{H \times N_{\% 100}}
$$

where:

$W=$ the weightings from the scale of 1 to 5 given by the respondents.

$H=$ the highest of the weighting, 5

$N=$ total number of research participants for the construction workgroups (150 each).

(Enshassi, et al., 2016; Fordjour, et al., 2019) [20] [46]. 


\section{Results of the Quantitative Study}

The Kaiser-Meyer-Olkin (KMO) value was greater than 0.50 as required (Norusis, 2001) [49]. The value of the Chi-Square under Bartlett's Test of Sphericity had a significant value of less than 0.05 . The measure of the sampling adequacy using Kaiser-Meyer-Olkin (KMO) were 0.823 and 0.839 for data collected on effects on construction employees and the construction industry respectively. The results of sphericity using Bartlett's test had approximate Chi-Square values of $3.952 \mathrm{E} 3$ and $2.161 \mathrm{E} 3$. The result from the test, therefore, confirms that factor analysis was appropriate, and that the data can be relied upon. The total number of 4 constructs extracted was based on Eigenvalues greater than 1. The cumulative total variance of the 2 constructs extracted each for the two measures were about $55 \%$ and $62 \%$. The results of the factor loadings from the principal component analysis have been presented in Table 6 and Table 7. The factor loadings were greater than 0.5, which is acceptable (Lo, 2018) [48].

The perceived effects of psychological disorders on employees were categorized under two main constructs, namely: behavioural effects and physiological effects. The perceived effects of psychological disorders on the construction industry were also categorized under two main constructs namely: direct costs and indirect costs. The reliability and internal consistency of the constructs had Cronbach alpha value above 0.70 , which is acceptable. The values of the Cronbach alpha of each item have been presented. All the perceived effects of psychological disorders analysed had mean values above 3.0. With the test value set at 3 , one sample T-test analysis also revealed that all perceived effects revealed in this study had p -values less than 0.05 as shown in Table 6 and Table 7, and therefore are deemed significant. The null hypothesis which states that the perceived effects of psychological disorders are not statistically significant will be rejected.

The data were revealed to be normally distributed by the Blom's fractional rank estimation test and hence the results obtained from the two construction groups could be compared for all the variables. Independent two-sample T-test was employed for the comparison of the mean scores of effects of psychological disorders on the construction employees and the construction industry as determined by the two construction groups, and the results presented in Table 8 and Table 9. The comparison was intended to determine whether the differences between the two construction working groups could influence their perceptions on the effects of psychological disorders.

Levene's Test for equality of variances among the two construction workgroups as presented in Table 8 and Table 9 indicated that the mean scores of the two construction groups were statistically significantly different for some of the variables. These items have their $\mathrm{p}$ - values less than 0.05 and marked with $\left.{ }^{*}\right)$ as shown in Table 8 and Table 9 . The null hypothesis which assumes no statistically significant differences between the mean scores of the two construction groups will be rejected and the alternative hypothesis that states otherwise will 
be accepted for these items of coping strategies. However, the null hypothesis will not be rejected for the other factors that revealed no statistically significant differences and assumed equal variances for the two construction working groups (Fordjour, et al., 2019) [47].

Table 6. Statistical results of perceived effects of psychological disorders on the construction employees.

\begin{tabular}{|c|c|c|c|c|c|c|}
\hline Code & $\begin{array}{c}\text { Effects on the } \\
\text { construction employees }\end{array}$ & Mean & $\begin{array}{l}\text { Std. } \\
\text { Dev. }\end{array}$ & $\begin{array}{l}\text { P-value } \\
\text { (Sig.) }\end{array}$ & $\begin{array}{l}\text { Factor } \\
\text { loadings }\end{array}$ & $\begin{array}{c}\text { Cronbach } \\
\text { alpha }\end{array}$ \\
\hline & \multicolumn{5}{|c|}{ Construct 1: Behavioural effects } & 0.827 \\
\hline E3 & $\begin{array}{l}\text { Lose valuable things like job, } \\
\text { relationships and status }\end{array}$ & 3.78 & 0.770 & 0.000 & 0.822 & 0.794 \\
\hline $\mathrm{E} 4$ & Loss memory/ forgetfulness & $4.08^{\star}$ & 0.741 & 0.000 & 0.740 & 0.787 \\
\hline E5 & Accident-prone & $4.18^{\star}$ & 0.672 & 0.000 & 0.595 & 0.819 \\
\hline E7 & Insomnia or sleep disturbances & $4.11^{\star}$ & 0.727 & 0.000 & 0.753 & 0.786 \\
\hline E11 & Family problems & 3.84 & 0.769 & 0.000 & 0.717 & 0.794 \\
\hline E12 & Sexual dysfunction & 3.64 & 0.744 & 0.000 & 0.731 & 0.859 \\
\hline E15 & $\begin{array}{c}\text { Loss of motivation, energy or } \\
\text { interest }\end{array}$ & 3.75 & 0.764 & 0.000 & 0.815 & 0.795 \\
\hline \multirow[t]{2}{*}{ E17 } & Dietary extremes & $4.06^{\star}$ & 0.738 & 0.000 & 0.709 & 0.813 \\
\hline & \multicolumn{5}{|c|}{ Construct 2: Physiological effects } & 0.822 \\
\hline E1 & Chronic pain & $4.14^{*}$ & 0.715 & 0.000 & 0.720 & 0.784 \\
\hline E2 & Coronary heart disease & 3.60 & 0.732 & 0.000 & 0.754 & 0.808 \\
\hline E6 & High blood pressure & 3.73 & 0.758 & 0.000 & 0.734 & 0.795 \\
\hline E8 & Stroke or Cancer & 3.67 & 0.741 & 0.000 & 0.676 & 0.798 \\
\hline E9 & Headache & 3.95 & 0.774 & 0.000 & 0.634 & 0.813 \\
\hline E10 & Musculoskeletal injuries & $4.09^{*}$ & 0.722 & 0.000 & 0.703 & 0.807 \\
\hline E13 & Diabetes mellitus & 3.47 & 0.691 & 0.000 & 0.617 & 0.809 \\
\hline E14 & Feeling faint or dizzy & 3.80 & 0.773 & 0.000 & 0.602 & 0.817 \\
\hline E16 & Tightness in the chest & 3.96 & 0.775 & 0.000 & 0.630 & 0.797 \\
\hline
\end{tabular}

Note: Variables with the highest mean scores of above 4.0 have their values marked with "»".

Table 7. Statistical results of the effects of construction employees' psychological disorders on the construction industry.

\begin{tabular}{ccccccc}
\hline Code & $\begin{array}{c}\text { Effects on the } \\
\text { construction industry }\end{array}$ & Mean & $\begin{array}{c}\text { Std. } \\
\text { Dev. }\end{array}$ & $\begin{array}{c}\text { P-value } \\
\text { (Sig.) }\end{array}$ & $\begin{array}{c}\text { Factor } \\
\text { loadings }\end{array}$ & $\begin{array}{c}\text { Cronbach } \\
\text { alpha }\end{array}$ \\
\hline \multicolumn{2}{c}{ Construct 1: Direct costs } & & $\mathbf{0 . 8 4 8}$ \\
\hline F1 & Poor work performance & 3.90 & 0.774 & 0.000 & 0.553 & 0.828 \\
F3 & Low productivity & 3.94 & 0.745 & 0.000 & 0.685 & 0.805 \\
F4 & High turnover & 3.85 & 0.781 & 0.000 & 0.714 & 0.829 \\
F7 & Absenteeism/ Sick leave & $4.14^{*}$ & 0.704 & 0.000 & 0.681 & 0.837 \\
F9 & Work stoppage & 3.68 & 0.762 & 0.000 & 0.538 & 0.845 \\
F11 & Medical costs & $4.00^{*}$ & 0.761 & 0.000 & 0.734 & 0.790 \\
\hline
\end{tabular}




\section{Continued}

\begin{tabular}{ccccccc}
\hline \multicolumn{7}{c}{ Construct 2: Indirect costs } \\
\hline F2 & Low motivation & 3.99 & 0.758 & 0.000 & 0.588 & 0.763 \\
F5 & Low morale & 3.70 & 0.764 & 0.000 & 0.578 & 0.790 \\
F6 & Job dissatisfaction & $4.03^{*}$ & 0.698 & 0.000 & 0.762 & 0.717 \\
F8 & $\begin{array}{c}\text { Breakdown in } \\
\text { communication }\end{array}$ & 3.57 & 0.683 & 0.000 & 0.640 & 0.743 \\
F10 & Violence at work & 3.65 & 0.763 & 0.000 & 0.763 & 0.724 \\
F12 & Errors in work & $4.05^{*}$ & 0.739 & 0.000 & 0.719 & 0.708 \\
\hline
\end{tabular}

Note: Variables with the highest mean scores of above 4.0 have their values marked with “*”.

Table 8. Comparison of the statistical results obtained from the construction professionals' group ${ }^{(a)}$ and construction trade workers group ${ }^{(b)}$.

\begin{tabular}{|c|c|c|c|c|c|c|}
\hline \multirow[t]{2}{*}{ Code } & $\begin{array}{l}\text { Effects on the } \\
\text { construction } \\
\text { employees }\end{array}$ & $\begin{array}{l}\text { Group } \\
\text { Mean }\end{array}$ & $\begin{array}{l}\text { Group } \\
\text { RII \% }\end{array}$ & \multicolumn{2}{|c|}{$\begin{array}{l}\text { Levene's Test for } \\
\text { Equality of Variances }\end{array}$} & \multirow[t]{2}{*}{$\begin{array}{l}\text { Group } \\
\text { Rank }\end{array}$} \\
\hline & \multicolumn{5}{|c|}{ Construct 1: Behavioural effects } & \\
\hline E3 & $\begin{array}{l}\text { Lose valuable things } \\
\text { like job, relationships } \\
\text { and status }\end{array}$ & $3.77^{\mathrm{a}}, 3.79^{\mathrm{b}}$ & $75.3^{\mathrm{a}}, 75.9^{\mathrm{b}}$ & 13.939 & $0.000^{*}$ & 9 th $^{\mathrm{a}}, 11 \mathrm{th}^{\mathrm{b}}$ \\
\hline $\mathrm{E} 4$ & $\begin{array}{l}\text { Loss memory/ } \\
\text { forgetfulness }\end{array}$ & $4.01^{\mathrm{a}}, 4.15^{\mathrm{b}}$ & $80.3^{\mathrm{a}}, 82.9^{\mathrm{b}}$ & 7.941 & $0.005^{\star}$ & $4 \mathrm{th}^{\mathrm{a}}, 7 \mathrm{th}^{\mathrm{b}}$ \\
\hline E5 & Accident-prone & $4.07^{\mathrm{a}}, 4.29^{\mathrm{b}}$ & $81.5^{\mathrm{a}}, 85.9^{\mathrm{b}}$ & 11.888 & $0.001^{\star}$ & $1 \mathrm{st}^{\mathrm{a}}, 4 \mathrm{th}^{\mathrm{b}}$ \\
\hline E7 & $\begin{array}{l}\text { Insomnia or sleep } \\
\text { disturbances }\end{array}$ & $4.04^{\mathrm{a}}, 4.19^{\mathrm{b}}$ & $80.8^{\mathrm{a}}, 83.7^{\mathrm{b}}$ & 10.481 & $0.001^{\star}$ & $3 \mathrm{rd}^{\mathrm{a}}, 6 \mathrm{th}^{\mathrm{b}}$ \\
\hline E11 & Family problems & $3.76^{\mathrm{a}}, 3.91^{\mathrm{b}}$ & $75.2^{\mathrm{a}}, 78.3^{\mathrm{b}}$ & 8.310 & $0.004^{*}$ & $10 \operatorname{th}^{\mathrm{a}}, 9 \mathrm{th}^{\mathrm{b}}$ \\
\hline E12 & Sexual dysfunction & $3.63^{\mathrm{a}}, 3.65^{\mathrm{b}}$ & $72.5^{\mathrm{a}}, 72.9^{\mathrm{b}}$ & 16.323 & $0.000^{*}$ & $14 \mathrm{th}^{\mathrm{a}}, 17 \mathrm{th}^{\mathrm{b}}$ \\
\hline E15 & $\begin{array}{l}\text { Loss of motivation, } \\
\text { energy or interest }\end{array}$ & $3.74^{\mathrm{a}}, 3.75^{\mathrm{b}}$ & $74.8^{\mathrm{a}}, 74.9^{\mathrm{b}}$ & 17.245 & $0.000^{*}$ & $11 \mathrm{th}^{\mathrm{a}}, 12 \mathrm{th}^{\mathrm{b}}$ \\
\hline \multirow[t]{2}{*}{ E17 } & Dietary extremes & $3.79^{\mathrm{a}}, 4.33^{\mathrm{b}}$ & $75.7^{\mathrm{a}}, 86.7^{\mathrm{b}}$ & 0.080 & 0.778 & $8 \mathrm{th}^{\mathrm{a}}, 2 \mathrm{nd}^{\mathrm{b}}$ \\
\hline & \multicolumn{6}{|c|}{ Construct 2: Physiological effects } \\
\hline E1 & Chronic pain & $3.92^{\mathrm{a}}, 4.37^{\mathrm{b}}$ & $78.4^{\mathrm{a}}, 87.3^{\mathrm{b}}$ & 0.258 & 0.612 & $6 \mathrm{th}^{\mathrm{a}}, 1 \mathrm{st}^{\mathrm{b}}$ \\
\hline $\mathrm{E} 2$ & Coronary heart disease & $3.49^{\mathrm{a}}, 3.71^{\mathrm{b}}$ & $69.7^{\mathrm{a}}, 74.1^{\mathrm{b}}$ & 35.553 & $0.000^{*}$ & $15 \operatorname{th}^{\mathrm{a}}, 14 \mathrm{th}^{\mathrm{b}}$ \\
\hline E6 & High blood pressure & $3.72^{\mathrm{a}}, 3.73^{\mathrm{b}}$ & $74.4,{ }^{\mathrm{a}} 74.7^{\mathrm{b}}$ & 17.816 & $0.000^{*}$ & $12 \mathrm{th}^{\mathrm{a}}, 13 \mathrm{th}^{\mathrm{b}}$ \\
\hline E8 & Stroke or Cancer & $3.69^{\mathrm{a}}, 3.66^{\mathrm{b}}$ & $73.7^{\mathrm{a}}, 73.2^{\mathrm{b}}$ & 22.952 & $0.000^{*}$ & $13 \mathrm{th}^{\mathrm{a}}, 16 \mathrm{th}^{\mathrm{b}}$ \\
\hline E9 & Headache & $4.06^{\mathrm{a}}, 3.85^{\mathrm{b}}$ & $81.2^{\mathrm{a}}, 76.9^{\mathrm{b}}$ & 24.156 & $0.000^{*}$ & $2 \mathrm{nd}^{\mathrm{a}}, 10 \mathrm{th}^{\mathrm{b}}$ \\
\hline E10 & Musculoskeletal injuries & $3.86^{\mathrm{a}}, 4.31^{\mathrm{b}}$ & $77.2^{\mathrm{a}}, 86.3^{\mathrm{b}}$ & 1.070 & 0.302 & $7 \mathrm{th}^{\mathrm{a}}, 3 \mathrm{rd}^{\mathrm{b}}$ \\
\hline E13 & Diabetes mellitus & $3.25^{\mathrm{a}}, 3.69^{\mathrm{b}}$ & $65.1^{\mathrm{a}}, 73.7^{\mathrm{b}}$ & 104.46 & $0.000^{*}$ & $17 \mathrm{th}^{\mathrm{a}}, 15 \mathrm{th}^{\mathrm{b}}$ \\
\hline E14 & Feeling faint or dizzy & $3.35^{\mathrm{a}}, 4.25^{\mathrm{b}}$ & $66.9^{\mathrm{a}}, 84.9^{\mathrm{b}}$ & 20.136 & $0.000^{*}$ & $16 \mathrm{th}^{\mathrm{a}}, 5 \mathrm{th}^{\mathrm{b}}$ \\
\hline E16 & Tightness in the chest & $3.94^{\mathrm{a}}, 3.98^{\mathrm{b}}$ & $78.8^{\mathrm{a}}, 79.6^{\mathrm{b}}$ & 8.253 & $0.004^{*}$ & $5 \operatorname{th}^{\mathrm{a}}, 8 \mathrm{th}^{\mathrm{b}}$ \\
\hline
\end{tabular}

Values marked with $\left({ }^{\mathrm{a}}\right)$ represent results from the construction professionals' group. Values marked with $\left(^{\mathrm{b}}\right)$ represent results from the construction trade workers' group. Values that indicate a statistically significant difference between the variances between the two groups are marked with ${ }^{*}$ ). 
Table 9. Comparison of the statistical results obtained from the construction professionals' group $^{(a)}$ and construction trade workers group ${ }^{(b)}$.

\begin{tabular}{|c|c|c|c|c|c|c|}
\hline \multirow[t]{2}{*}{ Code } & \multirow{2}{*}{$\begin{array}{l}\text { Effects on the } \\
\text { construction } \\
\text { industry }\end{array}$} & \multirow{2}{*}{$\begin{array}{l}\text { Group } \\
\text { Mean }\end{array}$} & \multirow{2}{*}{$\begin{array}{l}\text { Group } \\
\text { RII \% }\end{array}$} & \multicolumn{2}{|c|}{$\begin{array}{c}\text { Levene's Test for } \\
\text { Equality of Variances }\end{array}$} & \multirow{2}{*}{$\begin{array}{c}\text { Group } \\
\text { Rank }\end{array}$} \\
\hline & & & & $\mathrm{F}$-value & Sig. (Equal) & \\
\hline & \multicolumn{6}{|c|}{ Construct 1: Direct costs } \\
\hline $\mathrm{F} 1$ & Poor work performance & $3.85^{\mathrm{a}}, 3.95^{\mathrm{b}}$ & $76.9^{\mathrm{a}}, 79.1^{\mathrm{b}}$ & 2.253 & 0.134 & $5 \mathrm{th}^{\mathrm{a}}, 8 \mathrm{th}^{\mathrm{b}}$ \\
\hline F3 & Low productivity & $3.88^{\mathrm{a}}, 3.99^{\mathrm{b}}$ & $77.6^{\mathrm{a}}, 79.9^{\mathrm{b}}$ & 20.895 & $0.000^{*}$ & $4 \mathrm{th}^{\mathrm{a}}, 7 \mathrm{th}^{\mathrm{b}}$ \\
\hline $\mathrm{F} 4$ & High turnover & $3.52^{\mathrm{a}}, 4.18^{\mathrm{b}}$ & $70.4^{\mathrm{a}}, 83.6^{\mathrm{b}}$ & 1.980 & 0.160 & $10 \mathrm{th}^{\mathrm{a}}, 4 \mathrm{th}^{\mathrm{b}}$ \\
\hline F7 & Absenteeism/ Sick leave & $4.05^{\mathrm{a}}, 4.23^{\mathrm{b}}$ & $80.9^{\mathrm{a}}, 84.7^{\mathrm{b}}$ & 9.719 & $0.002^{*}$ & $1 \mathrm{st}^{\mathrm{a}}, 3 \mathrm{rd}^{\mathrm{b}}$ \\
\hline F9 & Work stoppage & $3.49^{\mathrm{a}}, 3.86^{\mathrm{b}}$ & $69.9^{\mathrm{a}}, 77.2^{\mathrm{b}}$ & 28.405 & $0.000^{*}$ & $11 \mathrm{th}^{\mathrm{a}}, 9 \mathrm{th}^{\mathrm{b}}$ \\
\hline \multirow[t]{2}{*}{ F11 } & Medical costs & $3.94^{\mathrm{a}}, 4.06^{\mathrm{b}}$ & $78.8^{\mathrm{a}}, 81.2^{\mathrm{b}}$ & 5.558 & $0.019^{*}$ & $3 \mathrm{rd}^{\mathrm{a}}, 6 \mathrm{th}^{\mathrm{b}}$ \\
\hline & \multicolumn{6}{|c|}{ Construct 2: Indirect costs } \\
\hline $\mathrm{F} 2$ & Low motivation & $3.73^{\mathrm{a}}, 4.24^{\mathrm{b}}$ & $74.7^{\mathrm{a}}, 84.8^{\mathrm{b}}$ & 0.003 & 0.959 & $6 \mathrm{th}^{\mathrm{a}}, 2 \mathrm{nd} \mathrm{d}^{\mathrm{b}}$ \\
\hline F5 & Low morale & $3.58^{\mathrm{a}}, 3.83^{\mathrm{b}}$ & $71.6^{\mathrm{a}}, 76.5^{\mathrm{b}}$ & 16.278 & $0.000^{*}$ & $8 \mathrm{th}^{\mathrm{a}}, 11 \mathrm{th}^{\mathrm{b}}$ \\
\hline F6 & Job dissatisfaction & $3.95^{\mathrm{a}}, 4.10^{\mathrm{b}}$ & $79.1,^{\mathrm{a}} 82.0^{\mathrm{b}}$ & 32.464 & $0.000^{*}$ & $2 \mathrm{nd}^{\mathrm{a}}, 5 \mathrm{th}^{\mathrm{b}}$ \\
\hline F8 & $\begin{array}{l}\text { Breakdown in } \\
\text { communication }\end{array}$ & $3.56^{\mathrm{a}}, 3.57^{\mathrm{b}}$ & $71.3^{\mathrm{a}}, 71.5^{\mathrm{b}}$ & 29.081 & $0.000^{*}$ & $9 \mathrm{th}^{\mathrm{a}}, 12 \mathrm{th}^{\mathrm{b}}$ \\
\hline F10 & Violence at work & $3.44^{\mathrm{a}}, 3.86^{\mathrm{b}}$ & $68.8^{\mathrm{a}}, 77.2^{\mathrm{b}}$ & 26.986 & $0.000^{*}$ & $12 \mathrm{th}^{\mathrm{a}}, 10 \mathrm{th}^{\mathrm{b}}$ \\
\hline F12 & Errors in work & $3.72^{\mathrm{a}}, 4.39^{\mathrm{b}}$ & $74.4^{\mathrm{a}}, 87.7^{\mathrm{b}}$ & 1.351 & 0.246 & $7 \mathrm{th}^{\mathrm{a}}, 1 \mathrm{st} \mathrm{b}^{\mathrm{b}}$ \\
\hline
\end{tabular}

Values marked with $\left({ }^{\mathrm{a}}\right)$ represent results from the construction professionals' group. Values marked with ( $\left.{ }^{\mathrm{b}}\right)$ represent results from the construction trade workers' group. Values that indicate a statistically significant difference between the variances between the two groups are marked with $\left.{ }^{*}\right)$.

\section{Discussions}

\subsection{The Perceived Effects of Psychological Disorders on the Construction Employees}

\section{Behavioural effects}

Occupational psychological disorders such as burnout, workaholism and depression can often cause behavioural disorders with associated symptoms such as poor memory, impaired concentration and fatigue or loss of energy (Schneid, 2005; Lerner, et al., 2004) [50] [51]. The study revealed perceived effects of psychological disorders on the construction employees which have been categorized under behavioural effects such as: lose valuable things like job, relationships and status, loss memory/forgetfulness, accident-prone, insomnia or sleep disturbances, family problems, sexual dysfunction, loss of motivation, energy or interest and dietary extremes. Accident-prone was highly rated by the research participants as the perceived effect of psychological disorders on construction employees. Similarly, Chan, et al., (2012) [23] advocated that disorders such as stress could affect the safety behaviours of construction employees.

Previous studies also revealed some effects of psychological disorders on the construction employees, which relates to behavioral effects such as depression 
(Bowen, et al., 2014a) [5], distress (Chan, et al., 2012) [23], anxiety (Leung, et al., 2017) [16], job dissatisfaction (Yang, et al., 2017) [15] and frustration (Chan, et al., 2016) [12]. The effects of occupational psychological disorders of burnout and workaholism could be seen in behavioural deviations such as overeating, loss of appetite, smoking, alcohol abuse, sleeping disorders, emotional outbursts, or violence and aggression (Leung, et al., 2016; Wang, et al., 2017; Leung and Chan, 2012) [2] [6] [9].

\section{Physiological effects}

Occupational psychological disorders such as burnout and workaholism have been linked with many types of physical ailments such as heart attack, high blood pressure, heart disease, peptic ulcer, headache, pain in the neck, asthma, and cancer (Mehta and Chaudhary, 2005; Enshassi, et al., 2016) [18] [20]. This study revealed perceived effects of occupational psychological disorders on the construction employees, which have been categorized under physiological effects such as chronic pain, coronary heart disease, stroke, cancer, headache, musculoskeletal injuries, diabetes mellitus, feeling faint or dizzy and tightness in the chest. Previous studies also revealed some effects of psychological disorders on the construction employees which relates to physiological effects such as fatigue during work (Boschman, et al., 2013) [3], migraines or headaches (Bowen, et al., 2014b) [14], gastrointestinal disorders (Chan, et al., 2012) [23], loss of appetite (Chan, et al., 2016) [12], sleep disorder (Bowen, et al., 2014a) [5], skin problems (Leung, et al., 2012) [13], back pain (Abbe, et al., 2011) [52], ulcer (Yang, et al., 2017) [15], heart attack (Enshassi, et al., 2016) [20] and blood pressure (Wang, et al., 2017) [9].

\subsection{The Perceived Effects of Psychological Disorders on the Construction Industry}

\section{Direct costs}

The impact of occupational psychological disorders in the workplace could have severe consequences not only for the employee but also for the organization (Hassard and Cox, 2016; Mehta and Chaudhary, 2005) [8] [18]. This study revealed perceived effects of construction employees' psychological health condition on the construction industry, which have been categorized under direct costs such as poor work performance, low productivity, high turnover, absenteeism or sick leave, work stoppage, medical costs. The key perceived effects of construction workers' psychological health conditions on the construction industry identified from the study were: absenteeism or sick leave and errors in work. This study was in conformity with a report by European Agency for Safety and Health at Work (2014) [53] which advocated that employees job performance, staff turnover, rates of accidents, illness and absenteeism are all affected by the psychological health condition of the employees. Other previous studies also revealed some direct costs as effects of psychological disorders on the construction industry such as low performance (Leung, et al., 2017) [16], low prod- 
uctivity (Chan, et al., 2016) [12], injury incidents (Abbe, et al., 2011) [52], absenteeism (Wang, et al., 2017) [9] and mistakes in work (Leung, et al., 2012) [13]. An individual worker suffering from psychological health conditions of burnout or workaholism would allocate fewer of his or her personal resources and capabilities needed to perform the assigned task efficiently (Boschman, et al., 2013; Yang, et al., 2017) [3] [15]. Even though the same amount of time will be spent on the task, the concentration level of the worker experiencing these psychological disorders will be minimal, and thus their work productivity will be decreased significantly (Chan, et al., 2012) [23]. The consequences of psychological health conditions of construction employees could, therefore, be devastating for the construction industry (Çelik and Oral, 2019; Wang, et al., 2017) [1] [9].

\section{Indirect costs}

Across various workplace, indirect cost claims such as low motivation and job dissatisfaction due to work-related psychological risks factors and employees' psychological health conditions have become predominant (Hassard and Cox, 2016; O’Donoghue, et al., 2016; McDaid, 2008) [8] [11] [54]. This study revealed perceived effects of construction employees' psychological health condition on the construction industry, which have been categorized under indirect costs such as low motivation, low morale, job dissatisfaction, breakdown in communication, violence at work and errors in decisions. Previous studies also revealed some indirect costs as effects of employees' psychological disorders on the construction industry such as poor relationship with others (Leung, et al., 2016) [2], intention to leave work (Chan, et al., 2016) [12] and decreased motivation (Wang, et al., 2017) [9]. These indirect costs could cause sickness presenteeism which refers to an employee being physically present at work, but cognitively or mentally absent (Burton, et al., 2004; Aronsson, et al., 2000) [55] [56]. Psychological health conditions such as burnout could cause changes to an individual's social and working life, with effects such as distancing from colleagues and friends, avoidance of communication at work and intention to leave work, with eventual consequences on overall project performance and outcome (Bowen, et al., 2014a; Abbe, et al., 2011) [5] [52]. Psychological health conditions of burnout and workaholism could, therefore, have some indirect cost as effects to the construction industry.

\section{Conclusions}

This study sort to identify the effects of occupational psychological disorders such as burnout and workaholism, on construction employees and the construction industry based on the perceptions, opinions or personal experiences of construction employees. To achieve this aim, this study adopted the methods of focus group discussions and questionnaire survey in Ghana. The focus group study provided in-depth information on the research topic. The participants for the study revealed seventeen (17) items as perceived effects of occupational psychological disorders on construction employees. The participants also revealed 
twelve (12) items as perceived effects of construction employees' psychological health conditions on the construction industry. A quantitative study was then conducted as further studies. The methods of exploratory factor analysis were employed, and the findings were categorized under major sub-headings. The perceived effects of psychological disorders on construction employees were categorized under behavioural effects and physiological effects. The perceived effects of construction workers' psychological health conditions on the construction industry were also categorized under direct costs and indirect costs. The internal consistency and reliability of the 4 constructs extracted were revealed to be good.

The results from the study indicated that all the items identified in this study as effects of occupational psychological disorders on construction employees and the construction industry were statistically significant. The null hypothesis stating that the perceived effects of psychological disorders were not statistically significant will be rejected, and the alternative hypothesis accepted. The key perceived effects of psychological disorders on construction employees identified were accident-prone, chronic pain, insomnia or sleep disturbances, musculoskeletal injuries, loss memory/forgetfulness as these had the highest mean scores. The key items also identified as perceived effects of construction employees' psychological health conditions on the construction industry were: absenteeism/sick leave, errors in work, job dissatisfaction and medical costs.

A comparison of the mean scores obtained from the construction professionals and construction trade workers revealed statistically significant differences for some of the items measured as effects of occupational psychological disorders. The null hypothesis which states that the mean scores obtained by the two construction groups were not statistically significant will also be rejected, and the alternative hypothesis accepted. The rankings of the items measured in the study also showed significant differences between the two construction groups. For instance, accident-prone as an effect of occupational psychological disorders on construction employees was ranked $1^{\text {st }}$ by the construction professionals but $4^{\text {th }}$ by the construction trade workers. Chronic pain was rather ranked $1^{\text {st }}$ by the construction trade workers but $6^{\text {th }}$ by the construction professionals. On the other hand, absenteeism/sick leave as an effect of occupational psychological disorders on the construction industry was ranked $1^{\text {st }}$ by the construction professionals but $3^{\text {rd }}$ by the construction trade workers. Errors in work as an effect was rather ranked $1^{\text {st }}$ by the construction trade workers but $7^{\text {th }}$ by the construction professionals. These results could be due to various reasons such as differences in the nature of work, professional skills, educational background, level of experience, levels of commitment and job responsibilities among the construction personnel. The findings from this study were also in conformity with some previous studies conducted in occupational psychology.

The results of this study indicate that there is a need for strategic interventions in the construction industry to mitigate the effects of occupational psychological 
disorders on construction employees and the construction industry. The consequences of construction employees' psychological health conditions on the construction industry also necessitate some measures by the construction stakeholders to enhance the well-being of construction employees. The limitation of the study includes the focus of the study in a single geographical area. A future study could conduct cross-cultural studies to determine whether the findings from the study would be different from other geographical settings.

\section{Recommendations}

This study recommends organisational strategies such as the provision of psychological health systems, interventions for psychological ill-being symptoms and employees support from management and co-workers, as measures to enhance occupational psychological health management in the construction industry. This study also recommends that construction employees experiencing some effects of psychological disorders should seek medical attention or consult a professional psychologist or counsellor for help. Support from family or friends and the adoption of a healthy lifestyle would also help moderate the effects of psychological disorders on the construction employees. The findings from the study would, therefore, enhance occupational psychological health management in the construction industry and contribute to the literature on occupational psychology.

\section{Acknowledgements}

This research work is fully sponsored by the Hong Kong PhD Fellowship Scheme of the Research Grants Council and supported by the Hong Kong Polytechnic University. This research paper is part of the corresponding author's research project from which other deliverables have been produced with different objectives but shares common background, methodology and research participants.

\section{Conflicts of Interest}

The authors declare no conflicts of interest regarding the publication of this paper.

\section{References}

[1] Çelik, G. and Oral, E. (2019) Mediating Effect of Job Satisfaction on the Organizational Commitment of Civil Engineers and Architects. International Journal of Construction Management, 1-17. https://doi.org/10.1080/15623599.2019.1602578

[2] Leung, M.Y., Liang, Q. and Yu, J. (2016) Development of a Mindfulness-Stress-Performance Model for Construction Workers. Construction Management and Economics, 34, 110-128. https://doi.org/10.1080/01446193.2016.1147652

[3] Boschman, J.S., Van Der Molen, H.F., Sluiter, J.K. and Frings-Dresen, M.H. (2013) Psychosocial Work Environment and Mental Health among Construction Workers. Applied Ergonomics, 44, 748-755. https://doi.org/10.1016/j.apergo.2013.01.004 
[4] Sommovigo, V., Ilaria, S., Maria, E.M. and Piergiorgio, A. (2019) Tunnel Construction Workers' Well-Being: The Role of Job Control and Supervisor Support. International Journal of Construction Management, 1-13. https://doi.org/10.1080/15623599.2019.1600276

[5] Bowen, P., Edwards, P., Lingard, H. and Cattell, K. (2014) Workplace Stress, Stress Effects, and Coping Mechanisms in the Construction Industry. Journal of Construction Engineering and Management, 140, 1-24. https://doi.org/10.1061/(ASCE)CO.1943-7862.0000807

[6] Leung, M.Y. and Chan, I.Y.S. (2012) Exploring Stressors of Hong Kong Expatriate Construction Professionals in Mainland China: Focus Group Study. Journal of Construction Engineering and Management, 138, 78-88. https://doi.org/10.1061/(ASCE)CO.1943-7862.0000411

[7] WHO-World Health Organization (2005) Mental Health Policies and Programmes in the Workplace (Mental Health Policy and Service Guidance Package). WHO, Geneva.

[8] Hassard, J. and Cox, T. (2016) Occupational Safety and Health Wikipedia Contributors Mental Health at Work. https://oshwiki.eu/index.php?title=Mental_health_at_work\&oldid=245971

[9] Wang, C., Mohd-Rahim, F.A., Chan, Y.Y. and Abdul-Rahman, H. (2017) Fuzzy Mapping on Psychological Disorders in Construction Management. Journal of Construction Engineering and Management, 143, 1-20. https://doi.org/10.1061/(ASCE)CO.1943-7862.0001217

[10] Lazarus, R.S. and Folkman, S. (1984) Stress, Appraisal, and Coping. Springer, New York.

[11] O’Donoghue, A., Conway, E. and Bosak J. (2016) Abusive Supervision, Employee Well-Being and Ill-Being: The Moderating Role of Core Self-Evaluations. Emotions and Organizational Governance. Research on Emotion in Organizations, 12, 3-34. https://doi.org/10.1108/S1746-979120160000012001

[12] Chan, I.Y.S., Leung, M.Y. and Liu, A.M.M. (2016) Occupational Health Management System: A Study of Expatriate Construction Professionals. Accident Analysis and Prevention, 93, 280-290. https://doi.org/10.1016/j.aap.2015.11.003

[13] Leung, M.Y., Chan, I.Y.S. and Yu, J. (2012) Preventing Construction Worker Injury Incidents through the Management of Personal Stress and Organizational Stressors. Accident Analysis and Prevention, 48, 156-166. https://doi.org/10.1016/j.aap.2011.03.017

[14] Bowen, P., Govender, R. and Edwards, P. (2014) Structural Equation Modelling of Occupational Stress in the Construction Industry. Journal of Construction Engineering and Management, 140, 1-14. https://doi.org/10.1061/(ASCE)CO.1943-7862.0000877

[15] Yang, F., Li, X., Zhu, Y., Li, Y. and Wu, C. (2017) Job Burnout of Construction Project Managers in China: A Cross-Sectional Analysis. International Journal of Project Management, 35, 1272-1287. https://doi.org/10.1016/j.ijproman.2017.06.005

[16] Leung, M.Y., Liang, Q. and Chan, I.Y.S. (2017) Development of a Stressors-Stress-Performance-Outcome Model for Expatriate Construction Professionals. Journal of Construction Engineering and Management, 143, 1-11. https://doi.org/10.1061/(ASCE)CO.1943-7862.0001266

[17] Finney, C., Stergiopoulos, E., Hensel, J., Bonato, S. and Dewa, C.S. (2013) Organizational Stressors Associated with Job Stress and Burnout in Correctional Officers: A Systematic Review. BMC Public Health, 13, 82-95. 
https://doi.org/10.1186/1471-2458-13-82

[18] Mehta, R.S. and Chaudhary, R.N. (2005) Job Related Stress among the Nurses Working in Critical Care Areas at BPKIHS, Nepal. Nursing and Midwifery Research Journal, 1, 70-76.

[19] Ganster, D.C. and Rosen, C.C. (2013) Work Stress and Employee Health: A Multidisciplinary Review. Journal of Management, 39, 1085-1122. https://doi.org/10.1177/0149206313475815

[20] Enshassi, A., Al Swaity, E. and Arain, F. (2016) Investigating Common Causes of Burnout in the Construction Industry. International Journal of Construction Project Management, 8, 1-15.

[21] Baba, V.V., Tourigny, L., Wang, X.Y. and Liu, W.M. (2009) Proactive Personality and Work Performance in China: The Moderating Effects of Emotional Exhaustion and Perceived Safety Climate. Canadian Journal of Administrative Sciences, 26, 23-37. https://doi.org/10.1002/cjas.90

[22] Chartered Institute of Building (CIOB) (2006) Occupational Stress in the Construction Industry: CIOB Published National Stress Survey Results.

https://policy.ciob.org/wp-content/uploads/2006/03/Occupational-Stress-in-the-Co nstruction-Industry-March-2006.pdf

[23] Chan, I.Y.S., Leung, M.Y. and Yu, S.W. (2012) Managing Stress of Hong Kong Expatriate Construction Professionals in Mainland China: Focus Group Studies to Exploring Individual Coping Strategies and Organizational Support. Journal of Construction Engineering and Management, 138, 1150-1160. https://doi.org/10.1061/(ASCE)CO.1943-7862.0000533

[24] Health and Safety Executive (2007) An Analysis of the Prevalence and Distribution of Stress in the Construction Industry. Report No. RR518, Health and Safety Laboratory, Derbyshire, UK. http://www.hse.gov.uk/research/rrpdf/rr518.pdf

[25] Fordjour, G.A. and Chan, A.P.C. (2019) Exploring Occupational Psychological Health Indicators among Construction Employees: A Study in Ghana. Journal of Mental Health and Clinical Psychology, 3, 6-18. https://doi.org/10.29245/2578-2959/2019/2.1177

[26] Russell, J.A. (2003) Core Affect and the Psychological Construction of Emotion. Psychological Review, 110, 145-172. https://doi.org/10.1037/0033-295X.110.1.145

[27] Kahya, E. (2007) The Effects of Job Characteristics and Working Conditions on Job Performance. International Journal of Industrial Ergonomics, 37, 515-523. https://doi.org/10.1016/j.ergon.2007.02.006

[28] Gruman, J.A. and Saks, A.M. (2011) Performance Management and Employee Engagement. Human Resource Management Review, 21, 123-136. https://doi.org/10.1016/j.hrmr.2010.09.004

[29] Millward, L.J. (2006) Research Methods in Psychology: Focus Groups. 3rd Edition, Sage Publications, London, 274-299.

[30] Offei, V. and Quansah, J. (2009) Principles of Public/Community Health Nursing: Practice and Disease Prevention in Ghana. Adonai Publications, Accra, Ghana.

[31] Loosemore, M. (2009) Managing Public Perceptions of Risk on Construction and Engineering Projects: How to Involve Stakeholders in Business Decisions. International Journal of Construction Management, 9, 65-74. https://doi.org/10.1080/15623599.2009.10773130

[32] Alarcon, G.M. (2011) A Meta-Analysis of Burnout with Job Demands, Resources, and Attitudes. Journal of Vocational Behavior, 79, 549-562. 
https://doi.org/10.1016/j.jvb.2011.03.007

[33] Maslach, C., Schaufeli, W.B. and Leiter, M.P. (2001) Job Burnout. Annual Review of Psychology, 52, 397-422. https://doi.org/10.1146/annurev.psych.52.1.397

[34] Demerouti, E., Bakker, A.B., Nachreiner, F. and Schaufeli, W.B. (2001) The Job Demands-Resources Model of Burnout. Journal of Applied Psychology, 86, 499-512. https://doi.org/10.1037/0021-9010.86.3.499

[35] Colman, A.M. (2003) Oxford Dictionary of Psychology. Oxford University Press Inc., New York.

[36] Demerouti, E., Mostert, K. and Bakker, A.B. (2010) Burnout and Work Engagement: A thorough Investigation of the Independency of Both Constructs. Journal of Occupational Health Psychology, 15, 209-222. https://doi.org/10.1037/a0019408

[37] Oates, W.E. (1971) Confessions of a Workaholic: The Facts about Work Addiction. World Publishing Company, New York.

[38] Van Beek, I., Hu, Q., Schaufeli, W.B., Taris, T.W. and Schreurs, B.H. (2012) For Fun, Love, or Money: What Drives Workaholic, Engaged, and Burned-out Employees at Work? Applied Psychology, 61, 30-55. https://doi.org/10.1111/j.1464-0597.2011.00454.x

[39] Spence, J.T. and Robbins, A.S. (1992) Workaholism: Definition, Measurement, and Preliminary Results. Journal of Personality Assessment, 58, 160-178. https://doi.org/10.1207/s15327752jpa5801_15

[40] McMillan, L.H.W., O’Driscoll, M.P. and Burke, R.J. (2003) Workaholism: A Review of Theory, Research, and Future Directions. International Review of Industrial and Organizational Psychology, 18, 167-190. https://doi.org/10.1002/0470013346.ch5

[41] Schaufeli, W.B., Taris, T.W. and Van Rhenen, W. (2008) Workaholism, Burnout, and Work Engagement: Three of a Kind or Three Different Kinds of Follower Well-Being? Applied Psychology, 57, 173-203. https://doi.org/10.1111/j.1464-0597.2007.00285.x

[42] Pennonen, M. (2011) Recovery from Work Stress. Antecedents, Processes and Outcomes. School of Social Sciences and Humanities, University of Tampere, Tampere, Finland.

[43] Ashleigh, M. and Mansi, A. (2012) The Psychology of People in Organizations. Pearson, London.

[44] Cooper, D.R. and Schindler, P.S. (2006) Business Research Methods. McGraw-Hill, Irwin, New York.

[45] Krueger, R.A. and Casey, M.A. (2000) Focus Groups. A Practical Guide for Applied Research. 3rd Edition, Sage Publications, Thousand Oaks, Canada.

[46] Fordjour, G.A., Chan, A.P.C., Amoah, P. and Tuffour-Kwarteng, L. (2019) Coping Strategies Adopted by Construction Employees to Deal with the Causes and Effects of Occupational Psychological Disorders: A Study in Ghana. Health, 11, 755-782. https://doi.org/10.4236/health.2019.116062

[47] Fordjour, G.A., Chan, A.P.C. and Amoah, P. (2019) Exploring Personal Factors That Might Influence the Vulnerability of Construction Employees to Occupational Psychological Disorders. Health, 11, 546-566. https://doi.org/10.4236/health.2019.115047

[48] Lo, R. (2018) Advanced Quantitative Methods, APSS6003. Unpublished Material: Lecture Notes. Hong Kong Polythetic University, Hong Kong.

[49] Norusis, M.J. (2001) SPSS 12.0, Statistical Procedures Companion. Prentice Hall, 
Prentice, NJ.

[50] Schneid, T.L. (2005) Stigma as a Barrier to Employment: Mental Disability and the Americans with Disabilities Act. International Journal of Law and Psychiatry, 28, 670-690. https://doi.org/10.1016/j.ijlp.2005.04.003

[51] Lerner, D., Adler, D.A., Change, H., Berndet, E.R., Ireish, J.T., Lapitsky, L., Hood, M., Reed, J. and Rogers, W. (2004) The Clinical and Occupational Correlates of Work Productivity Loss among Employed Patients with Depression. Journal of Occupational and Environmental Medicine, 46, 46-55.

https://doi.org/10.1097/01.jom.0000126684.82825.0a

[52] Abbe, O.O. Harvey, C.M., Ikuma, L.H. and Aghazadeh, F. (2011) Modelling the Relationship between Occupational Stressors, Psychosocial/Physical Symptoms and Injuries in the Construction Industry. International Journal of Industrial Ergonomics, 41, 106-117. https://doi.org/10.1016/j.ergon.2010.12.002

[53] European Agency for Safety and Health at Work (2014) Calculating the Cost of Work-Related Stress and Psychosocial Risks. Office for Official Publications of the European Communities, Luxembourg.

[54] McDaid, D. (2008) Mental Health in Workplace Settings: Consensus Paper. European Commission, Luxembourg.

[55] Burton, W.N., Pransky, G., Conti, D.J., Chen, C.Y. and Edington, D.W. (2004) The Association of Medical Conditions and Presenteeism. Journal of Occupational and Environmental Medicine, 46, 38-45. https://doi.org/10.1097/01.jom.0000126687.49652.44

[56] Aronsson, G., Gustafsson, K. and Dallner, M. (2000) Sick But Yet at Work. An Empirical Study of Sickness Presenteeism. Journal of Epidemiological Community Health, 54, 502-509. https://doi.org/10.1136/jech.54.7.502 